\title{
Extensive subcutaneous emphysema in severe asthma
}

\author{
Takato Ikeda, Yoshiaki Kinoshita, Hisako Kushima, Hiroshi Ishii
}

Department of Respiratory Medicine, Fukuoka University Chikushi Hospital, Chikushino, Japan

\section{Correspondence to} Professor Hiroshi Ishii; hishii@fukuoka-u.ac.jp

Accepted 26 August 2021

\section{DESCRIPTION}

A 61-year-old woman with a history of asthma presented to the emergency department with wheezing and dyspnoea. Her oxygen saturation was $82 \%$ while breathing ambient air, and a chest radiograph showed no signs of pneumonia or pneumothorax. Despite the use of epinephrine, bronchodilators and systemic corticosteroids, the patient's respiratory condition did not improve and intubation was necessary on the day of the visit. Subsequently, pneumothorax developed on the right side and a chest tube was placed. On hospital day 3, crepitus appeared and spread from her head to her lower limbs. CT revealed right pneumothorax, pneumomediastinum and massive subcutaneous emphysema from the chest to the abdomen (figure 1). The patient's subcutaneous emphysema with pneumothorax and the exacerbation of asthma gradually resolved, and she was extubated on hospital day 13 .

A pathophysiological process of pneumomediastinum is known as the Macklin effect, ${ }^{1}$ which is summed up in three steps: alveolar ruptures, air dissection along bronchovascular sheaths and spreading of this pulmonary interstitial emphysema into the mediastinum. The Macklin effect

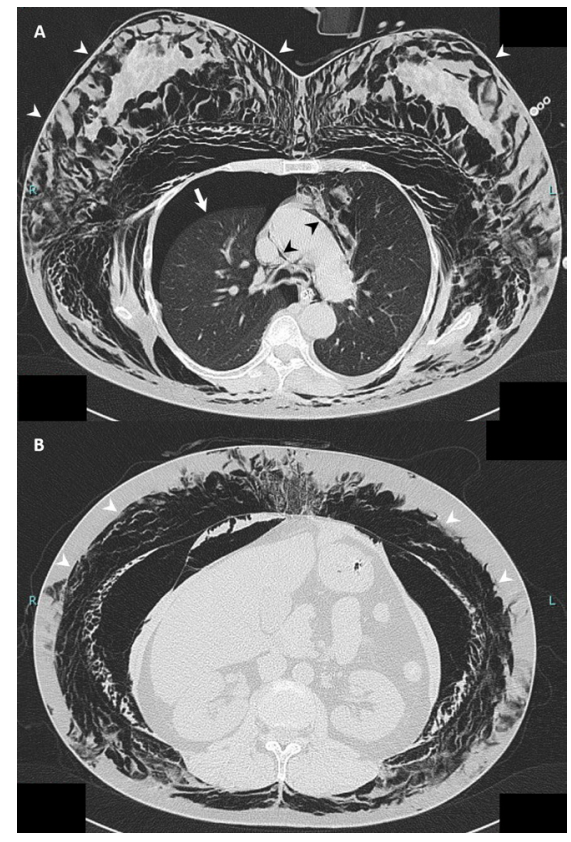

Figure 1 High-resolution CT showing right pneumothorax $(A$, arrow), pneumomediastinum $(A$, black arrowheads) and massive subcutaneous emphysema from the chest to the abdomen ( $A$ and $B$, white arrowheads). is involved in pneumomediastinum that occurs in a variety of conditions, including asthma attack, blunt trauma, mechanical ventilation and Valsalva manoeuvres. As the mechanism of pneumomediastinum and subcutaneous emphysema in the present case, an increased intrathoracic pressure associated with asthma attack and mechanical ventilation might cause secondary alveolar hyperextension and rupture of the alveolar wall. The thoracic drainage for pneumothorax could also have an impact in the present case. The leaked air might travel through the sparse vascular sheath of the tissue and leak from the hilum to mediastinum, and an increased mediastinal pressure might form subcutaneous emphysema via the cervical fascia. ${ }^{1}$ Some increased mediastinal pressure might enter the right pleural space after a rupture of mediastinal pleura.

\section{Patient's perspective}

I will be glad to be of help for the future healthcare.

\section{Learning points}

- An increased intrathoracic pressure associated with asthma attack and mechanical ventilation due to the Macklin effect may form mediastinal emphysema. If it progresses further, it may cause subcutaneous emphysema and pneumothorax.

- The thoracic drainage for pneumothorax may enhance subcutaneous emphysema.

Contributors $\mathrm{Tl}$ and $\mathrm{HI}$ researched the topic and wrote the case. YK and HK helped with the research and proofreading of the case report.

Funding The authors have not declared a specific grant for this research from any funding agency in the public, commercial or not-for-profit sectors.

Competing interests None declared.

Patient consent for publication Obtained.

Provenance and peer review Not commissioned; externally peer reviewed.

ORCID iD

Hiroshi Ishii http://orcid.org/0000-0002-2143-5922

\section{REFERENCE}

1 Macklin MT, Macklin CC. Malignant interstitial emphysema of the lungs and mediastinum as an important occult complication in many respiratory diseases and others conditions: interpretation of clinical literature in light of labolatory experiment. Medicine $1944 ; 23: 281-358$ 
Copyright 2021 BMJ Publishing Group. All rights reserved. For permission to reuse any of this content visit https://www.bmj.com/company/products-services/rights-and-licensing/permissions/

BMJ Case Report Fellows may re-use this article for personal use and teaching without any further permission.

Become a Fellow of BMJ Case Reports today and you can:

- Submit as many cases as you like

- Enjoy fast sympathetic peer review and rapid publication of accepted articles

Access all the published articles

Re-use any of the published material for personal use and teaching without further permission

Customer Service

If you have any further queries about your subscription, please contact our customer services team on +44 (0) 2071111105 or via email at support@bmj.com.

Visit casereports.bmj.com for more articles like this and to become a Fellow 